\title{
The Effect of Cannula Material on The Pain of Peripheral Intravenous Cannulation in the Emergency Department: A Prospective, Randomized Controlled Study
}

\author{
Acil Servisteki Periferik İntravenöz Kanül Uygulamalarında, \\ Kullanılan Kanül Materyalinin Girişim Ağrısı Üzerine Etkisi: \\ Prospektif, Randomize Kontrollü Çalışma
}

\author{
Murat ÖZSARAÇ, ${ }^{1}$ Meral DOLEK, ${ }^{2}$ Münevver SARSILMAZ, ${ }^{1}$ Mustafa SEVER, ${ }^{3}$ Serkan SENER, ${ }^{4}$ \\ Selahattin KiYAN, ${ }^{1}$ Aslihan YÜRÜKTÜMEN, ${ }^{5}$ GÜlbin YILMAZ' \\ 'Department of Emergency Medicine, Ege University Medical Faculty Hospital, Izmir; \\ ${ }^{2}$ Department of Emergency Medicine, Medical Park Izmir University Medical School Hospital, Izmir; \\ 3/zmir Tepecik Training and Research Hospital, Emergency Service, Izmir, \\ ${ }^{4}$ Department of Emergency Medicine, Acibadem University School of Medicine Hospital, Istanbul; \\ ${ }^{5}$ Department of Emergency Medicine, Akdeniz University Faculty of Medicine, Antalya, all in Turkey
}

\begin{abstract}
SUMMARY
Objectives

The present study was undertaken to compare the pain of peripheral IV cannulation (IVC) using a 20-G peripheral biomaterial PEU-Vialon cannula or the 20-G compound FEP-Teflon cannula widely used in clinical practice.

Methods

A prospective, randomized, single-blinded, controlled trial was undertaken at the ED of University Hospital. Eighty-nine noncritically ill adult patients who were receiving an IV line as part of their care were enrolled. In each case cannulas were applicated to the antecubital area. Participants rated their pain on a visual analog scale (VAS). The primary outcome was patients pain score, and the secondary outcome was the provider's perception of safety and satisfaction.
\end{abstract}

\section{Results}

The two treatment groups did not differ in age, gender or cannulation indication ( $p>0.05$ ). Mean VAS was 2.80 for PEU and 3.56 for FEP $(p=0.061)$. Mean provider safety scores were 4.84 (4 to 5 ) in the PEU group and 4.00 ( 2 to 5$)$ in the FEP group ( $p=0.0001)$. Mean provider satisfaction of application scores were 4.65 in the PEU group and 4.56 in the FEP group ( $p>0.05)$.

\section{Conclusions}

Althogh provider safety perception is high, perception of pain has not reduced when inserting PEU-Vialon cannula compared with compound of FEP.

Key words: Analgesia; cannulation; emergency medicine; pain; pain measurement.

\begin{abstract}
ÖZET
Amaç

Bu çalışma, klinik pratikte yaygın olarak kullanılan, 20-G periferik FEPTeflon kanül ile 20-G PEU-biyomateryal Vialon kanülün, periferik IV yoldan uygulanması esnasında, hastalarda gelişen ağrıyı karşılaştırmak amacıyla yapıldı.
\end{abstract}

\section{Gereç ve Yöntem}

Çalışma bir üniversite hastanesi acil servisinde prospektif, randomize, tek kör ve kontrollü olarak yapıldı. Acile kritik olmayan şikayetler ile başvuran, genel tıbbi bakımlarının bir parçası olarak IV yoldan damar yolu açılacak, seksen dokuz erişkin hasta çalışmaya alındı. Tüm IV damar yolu açılması uygulamaları antekübital alan üzerinden yapıldı. Çalışmaya katılanların işlem esnasındaki ağrıları görsel analog skala (VAS) ile değerlendirildi.

\section{Bulgular}

İki tedavi grubunda yaş, cinsiyet veya kanülasyon göstergesi farklı değildi ( $p>0.05$ ). Hastaların ortalama VAS skoru PEU kateter uygulananlar için 2.80 , FEP kateter uygulananlar için 3.56 idi $(p=0.061)$. Uygulayıcıların ortalama güvenlik algısı puanları PEU kateter uygulamaları için (4-5) 4.84, FEP kateter uygulamaları için (2-5) 4.00 olarak tespit edildi $(p=0.001)$. Uygulayıcıların ortalama memnuniyet puanlarının; PEU kateter uygulamaları için 4.65 ve FEP için 4.56 olduğu belirlendi ( $p>0.05)$.

\section{Sonuç}

Intravenöz yoldan kateter uygulamalarında, PEU-Vialon kateterlerin, FEPTeflon içerikli kateterler ile karşılaştıııldığında, hastalarda ağrı skorunu azaltmadığı ancak, mevcut güvenlik sağlayıcı kapaklarından dolayı, uygulayıılarda yüksek işlem güvenliği algısı oluşturduğu belirlendi.

Anahtar sözcükler: Analjezi; kanülasyon; acil tıp; ağrı; ağrı ölçümü.

Submitted (Geliş tarihi): 27.06.2012 Accepted (Kabul tarihi): 01.10.2012

Correspondence (Illetişim): Dr. Murat Özsaraç. Ege Üniversitesi Tıp Fakültesi Hastanesi, Acil Tıp Anabilim Dalı, Bornova, 35100 İzmir, Turkey e-mail (e-posta): mozsarac@msn.com 


\section{Introduction}

Insertion of Intravenous Cannulas is probably the most commonly performed invasive medical procedure in emergency department (ED). A number of strategies to minimize the pain of intravenous cannulation (IVC) for patients include; local buffered lidocaine of skin infiltration, application of topical lidocaine, ${ }^{[1]}$ liposomal lidocaine, ${ }^{[2]}$ prilocaine, tetracain, ${ }^{[3-5]}$ diclofenac patch, ${ }^{[6]}$ ibuprofen, piroxicam, ${ }^{[7]}$ myolaxin $^{[8]}$ and ice. ${ }^{[9]}$ Examples of the latter alternatives include alkane vapocoolant spray ${ }^{[10,11]}$ inhaled nitrous oxide, ${ }^{[12,13]}$ jet injector lidocaine, ${ }^{[14,15]}$ laser-assisted anesthesia, ${ }^{[16,17]}$ low-frequency ultrasound ${ }^{[18]}$ and distraction tactics as valsalva ${ }^{[19]}$ and cough trick, ${ }^{[20]}$ with variable results. Each technique has advantages as well as limitations, especially in the ED setting. Although pain and anxiety can be reduced by pretreating with local anesthetics, it is unclear which pretreatment technique is most effective. Application of anesthetic cream is one of the most popular technique for reducing pain during IV insertion, but the utility of these creams in a busy clinical setting such as the ED is limited by their delayed onset of action. ${ }^{[1]}$ As a result, clinicians have continued to seek ways to reduce the pain of IVC. ${ }^{[16]}$

The effect of the type of cannula material on the the pain of IVC has been less widely studied. Although most peripheral IVC's are made of tetrafluoroethylene-hexafluoropropylene (FEP-Teflon), catheters made of polyurethanes (PEU-Vialon) are also available (Fig. 1). A catheteter material, polyetherurethane is based on polytetramethylene ether glycol, 4.4'-diphenylmethane diiosocyanate, and 1.4-butanediol. It has a

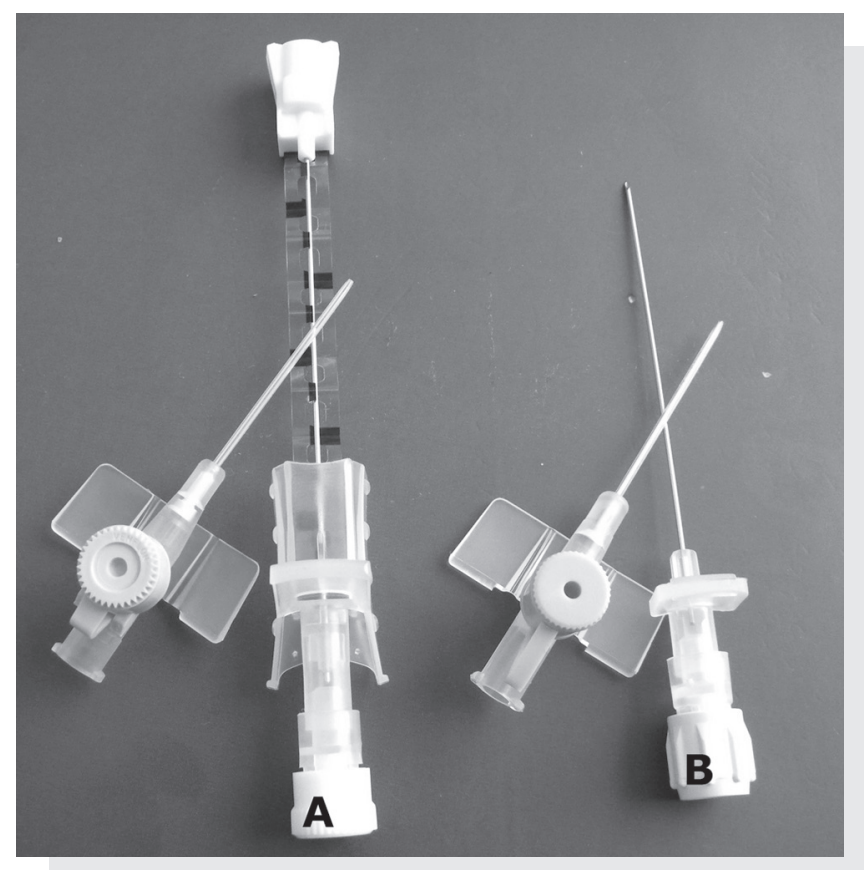

Figure 1. A. Polyurethane vialon catheter B. Teflon catheter. smoother microsurface, thermoplastic and more hydrophilic, makes it much more flexible than teflon at body temperature $^{[21]}$ (Fig. 2). The aim of this study was to compare the pain of IVC with FEP-Teflon and PEU-Vialon.

\section{Materials and Methods}

\section{Setting and Selection of Participants}

The study was conducted at a university ED which has emergency medicine residency program with an annual patient census of approximately 100.000 . This was a prospective, randomized, controlled and single-blinded study designed to compare the pain of peripheral IVC between 20-G peripheral autoguard shielded PEU-Vialon (BD-Venflon, BectonDickinson, UK) and 20-G compound of FEP-Teflon cannula (Bicakcilar, Turkey) widely used in clinical practice in many ED. Patients were enrolled in January 2010 to December 2010 within weekdays and working hours. Historical and demographic information were recorded on a standardized data collection form. Eligible patients were 18 to 60 years requiring acute peripheral IVC as a component of their evaluation and treatment. Participants Canadian Emergency Department Triage and Acuity Scale (CTAS) were 4.5. Patients with any type of pain and the ones that take analgesics within 24 hours were excluded from the study. Patients were also excluded if the vein has been recently used for an infusion, with abnormal skin conditions (broken skin, infection, scar, eczema or urticaria) at the site of venous puncture, chronic renal or liver disease, malignancy, stroke, mental disorder and refusal to participate the study. The study was approved by the institutional review board. Informed consent was obtained from all volunteers prior to enrollment.

We enrolled a convenience sample comprising patients who met the inclusion criteria during periods while the investigators were present in the ED (mainly 9 am to 5 pm on weekdays). Patients were assessed and managed according to

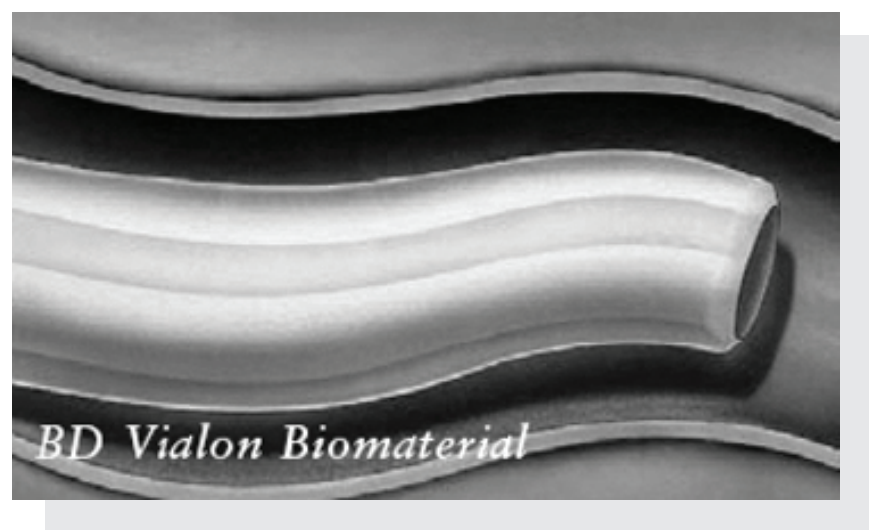

Figure 2. Flexible thermoplastic PEU-Vialon peripheral intravenous catheters. 
Table 1. Flow of patients through the trial

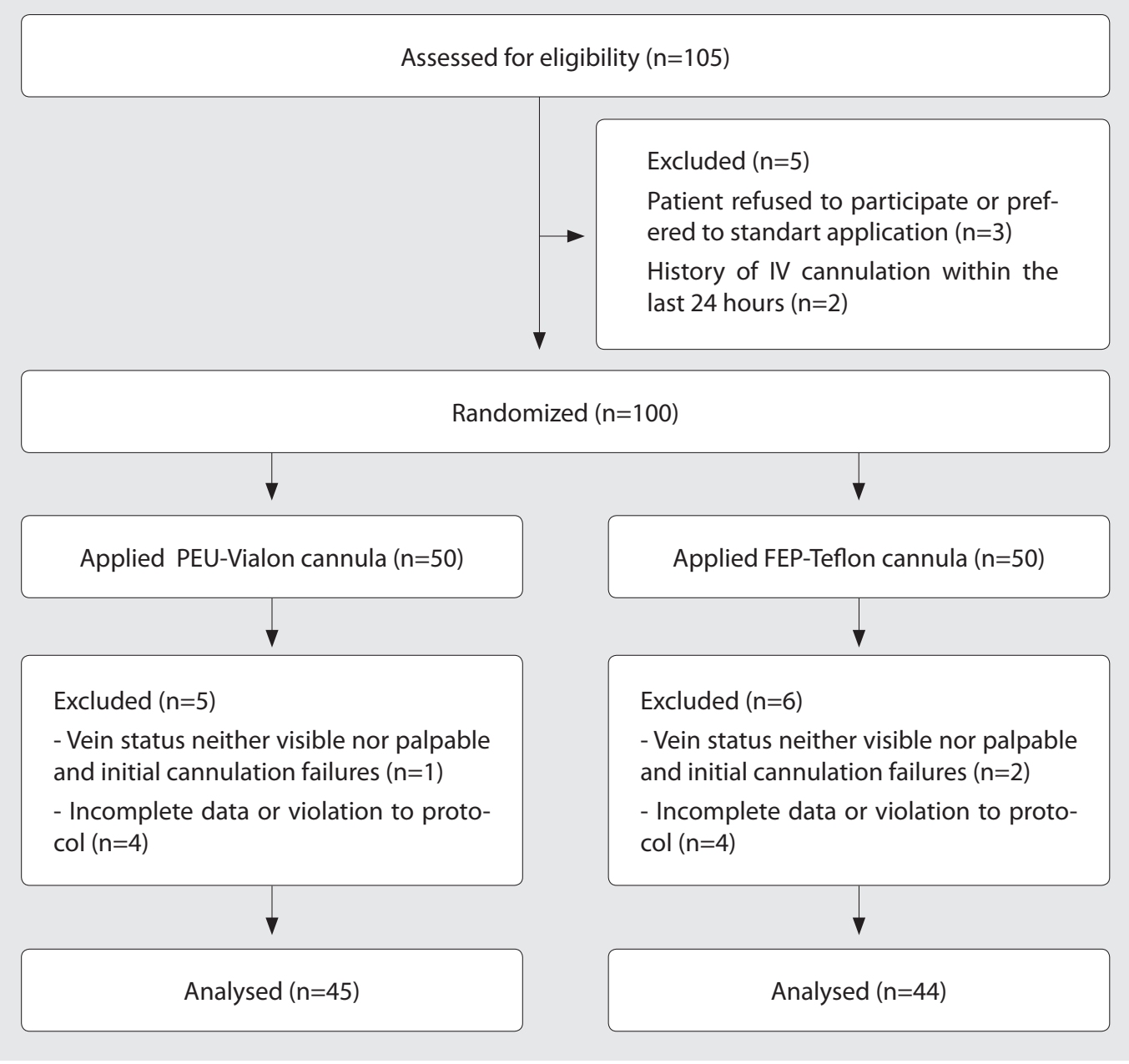

standard practice. After informing the patients and obtaining the written informed consents, series of opaque, consecutively numbered envelopes were opened to reveal the type of canulla to be applicated to the subjects. Participating patients were randomly assigned to apply PEU or FEP. Group assignment was determined by computer generated codes, thus ensuring an equal distribution of participants. Patients were randomized by an independent pharmacy assistant. Patients were unaware of the differences between cannula. Providers had no varying prominent experience in IVC. All cannula were inserted by four independent ED nurses with similar experience in the means of working years. Vein status was evaluated as veins neither visible nor palpable, veins visible but not palpable and veins clearly visible and easily palpable. Assessments and applications were made by the provider nurses. The providers choose the IVC site, applied a tourniquet, prepared the site with isopropyl alcohol, and inserted the cannula. All peripheral cannula were inserted using strict aseptic technique and secured using a sterile transparent dressing. For this study, insertion of the cannula was limited to the antecubital fossa. In each case cannula were sited on antecubital area of approximately $10-12 \mathrm{~cm}^{2}$, at cephalic vein, median cephalic vein or accessory cephalic vein in the forearm. We measured the time from the start of searching for an appropriate vein (after the tourniquet was applied) to successful insertion of the cannula. Successful insertion was defined as free flow of blood out of the inserted IV catheter. Likewise, we recorded the number of failed first attempts. Following venous cannulation, patients were asked whether they experienced pain. Another nurse or staff who was also blinded to group allocation, collected data and recorded perception of the pain scores as rated by patients on a visual analogue scale (VAS) $0-100 \mathrm{~mm}(0=$ no pain, $100=$ most painful). Patients whose veins could not be cannulated successfully on the first attempt were considered as initial cannulation failures and withdrawn from the study analysis. Besides the subjects vein status neither visible nor palpable were also excluded from the study analysis. After each IVC attempt, providers assessed their level of perceptions in the means of safety and satisfaction on a five-point Likert scale. 
Primary outcomes were participants' ratings of the pain of IVC by PEU or FEP groups. This was the pain measured immediately after cannulation using a validated visual analog pain scale marked "most pain" at the high end. ${ }^{[22]}$ Secondary outcomes were the time for successful insertion and perceptions of the providers' safety and satisfaction. The providers reported Likert scales on satisfaction (range, 1-5: 1=very dissatisfied and $5=$ very satisfied). Finally, they rated their overall perceptions of safety for the cannula they use on a five-point Likert scale from "not at all" to "very much". All collected data were analyzed to reduce bias against participants who partially completed the study.

\section{Statistical Analysis}

Continuous data (the severity of pain, perception of provider's safety and satisfaction) were summarized as means and $95 \%$ confidence intervals (95\% Cls) and compared with Student t-test. Discrete variables (gender, vein status, clinical properties) were compared by chi-square statistics. SPSS 14.0 (SPSS Inc, Chicago, IL, U.S.A.) was used for statistical analysis. $\mathrm{p}<0.05$ was considered as significant.

\section{Results}

A total of 105 patients were enrolled over a 12 month period. Totally 16 subjects were excluded from the study (Table 1). Mean age was 33.38 \pm 11.4 years (range of 18-59); 32 subjects (36\%) were man. Groups were similar with respect to demographic and clinical characteristics (Table 2). There were no statistically significant differences in these variables between the treatment groups. The mean duration of the vascular access procedure for each treatment group was approximately 5 to 10 seconds. There was no statistically significant difference in mean procedure duration between PEU and FEP groups ( $p=0.685)$. Most IVC (97\%) were successful at the first attempt. Pain scores: The mean pain score of catheter insertion on FEP group was $3.56 \mathrm{~mm}( \pm 2.02 \mathrm{~mm})$; the mean pain score for the PEU group was $2.80 \mathrm{~mm}( \pm 1.79$ $\mathrm{mm}$ ). The difference between the mean pain scores did not reach to statistical significance when compared by using the t-test $(p=.061)$ Satisfaction and Safety: There was no difference in the perception of providers' satisfaction between the FEP and PEU groups. However, there were remarkable difference in the perception of providers' safety between the groups $(p=.000)$ (Table 3$)$.

\section{Discussion}

IVC is a common procedure in the ED and it is also an uncomfortable experience for many patients. ${ }^{[11]}$ Although guidelines call for multimodal management strategies for needlestick pain, compliance with recommendations is often poor in practice ${ }^{[23]}$ Less than half of the medical doctors use local anesthetic for insertion of large bore intravenous cannula.

Table 2. Baseline characteristics of patients participating in the trial

\begin{tabular}{lccc}
\hline Characteristic & PEU (n=45) & FEP (n=44) & p \\
\hline Demographic & & & \\
Age, mean (SD), yr & $33.4(11.6)$ & $33.2(11.5)$ & 0.44 \\
Male, no. (\%) & $15(37.8)$ & $17(34.1)$ & 0.82 \\
Clinical & & & 0.08 \\
Benign positional vertigo & 15 & 14 & \\
Urticaria & 11 & 13 & \\
Acute enteritis & 13 & 17 & \\
Fever & 6 & - & \\
Provider's assessment of the vein & & 38 & \\
Veins clearly visible and easily palpable & 41 & 6 & \\
Veins visible but not palpable & 4 & &
\end{tabular}

Table 3. Comparison of Material of Intravenous Insertion

\begin{tabular}{lcccc}
\hline & PEU & FEP & P & t \\
\hline Pain score (mean) & 2.80 & 3.56 & 0.061 & 1.895 \\
Perception of provider's satisfaction (mean) & 4.64 & 4.56 & 0.573 & -0.566 \\
Perception of provider's safety (mean) & 4.84 & 4.00 & $0.000^{*}$ & -6.332 \\
\hline
\end{tabular}


Furthermore, less than $20 \%$ of all doctors used any local anesthetic for the most commonly used cannula (20 Gauge). ${ }^{[24]}$ Some reasons for caregivers overlooking a patient's pain include the subjective nature of pain and the potential for caregivers to minimize the effect, or diminish the seriousness or psychological impact, of a patient's pain. ${ }^{[25]}$ Barriers to implementation of the guidelines are manifold and include a lack of knowledge among health care professionals regarding available pain assessment, as well as perceived time constraints and inconvenience for administering local anesthetics. ${ }^{[26]}$ As a result, most ED patients have venous cannulation performed without any pretreatment with an anesthetic agent or device. Emergency practitioners should strive to reduce pain safely and effectively in all of their patients. ${ }^{[27]}$ The ideal method for local anesthesia before IVC in the ED should be effective, fast, portable, require little training, cause no significant deviation from the usual routine, have no additional biologic or physical risks to the patient or the health care provider, and should eliminate sharps disposal and handling precautions. No commercially available modality has been shown to be as effective or faster. ${ }^{[14]}$ This is the first study to assess the effect of canulla on the degree of pain experienced on IV insertion. We found PEU-Vialon cannula did not significantly reduce patients' perception of pain when compared with compound of FEP. Nociceptors are sensory end organs in the skin, muscle, joints and viscera that selectively respond to noxious or potentially tissuedamaging stimuli. An important property of nociceptors is that they sensitize. Sensitization, which typically develops as a consequence of tissue insult and inflammation, is defined as a reduction in the threshold and an increase in the magnitude of a response to noxious stimulation. ${ }^{[28]}$ Future investigation could aid in elucidating the role of the produce by means of nanotechnology products of related to cannula effect on mechanical tissue inflammation. Pain perception might influenced by anxiety, underlying conditions, culture and many other factors. However, strengths of this study are the use of blinding and enrolling only patients presenting with similar symptoms other than pain. More severe complaints might be more attentive to the pain of an IV insertion. Different locations in the body are more sensitive to pain than others. Clinical pain has an emotional component not present in experimental pain. ${ }^{[29]}$ Another strength of this study is the IVC applied to the same location of all patients.

Health care is one of the areas scarcely subjected to research on work-related injuries in developing countries, especially in Turkey. These injuries commonly are overlooked and neglected by health care workers in the developing countries. Needlestick injuries and sharps injuries are the most common work-related injuries in EDs, where health care is incessant for 24 hours a day, 7 days a week. \%14 of all work related injuries secondary to IV catheter applications. ${ }^{[30]}$
Commercially available intravenous catheters such as PEUViolan with self-capping needles have been associated with a significant reduction in the absolute number of inadvertent needlestick injuries. Related data could not be obtained in our country. In the era of human immunodeficiency virus (HIV) and hepatitis, safety of those placing IV lines cannot be overemphasized. Universal precautions must be applied to all patients, especially in emergency care settings in which the risk of blood exposure is increased and the infection status of patients is largely unknown. The protective IV catheter safety system has a protective sleeve that encases the sharp stylet as it is retracted from the catheter. ${ }^{[31]}$ An PEU-Vialon catheters used in this study, needle shield once activated, the needle tip is fully encapsulated inside the protection mechanism, which is designed to minimize the risk of injuries. This study have shown that, perceive of safety during IV insertion by protective IV catheter system.

There are a couple of limitations that need to be acknowledged and addressed regarding the present study. First this study was not placebo controlled and independent providers were not blinded as to which cannula applied. Thereby any systematic bias could not be eliminated. Severity of anxiety of participant were also not recorded. The patient severity and status were all subacute and mild; CTAS 4 or 5 , however, more severely anxious participant might be more reactive of an IVC. The relatively small sample size (105 patients) and relatively small number of hours analyzed (workhours between 08:00-17:00) could limit generalizability. Study population was composed of the subjects admitted in the emergency department within working hours and weekdays which may also cause bias.

\section{Conclusions}

Althogh provider safety perception is high, perception of pain has not reduced when inserting PEU-Vialon cannula compared with compound of FEP.

\section{Acknowledgements}

We thank providers nurse in the emergency department and Gul Kitapcioglu in Biostatistics and Medical Informatics. BD Medical and (Selim Ates) BALKEM Medical provided the IV canulla material used in the study.

\section{References}

1. McNaughton C, Zhou C, Robert L, Storrow A, Kennedy R. A randomized, crossover comparison of injected buffered lidocaine, lidocaine cream, and no analgesia for peripheral intravenous cannula insertion. Ann Emerg Med 2009;54:214-20.

2. Eidelman A, Weiss JM, Lau J, Carr DB. Topical anesthetics for dermal instrumentation: a systematic review of randomized, controlled trials. Ann Emerg Med 2005;46:343-51. 
3. Sawyer J, Febbraro S, Masud S, Ashburn MA, Campbell JC. Heated lidocaine/tetracaine patch (Synera, Rapydan) compared with lidocaine/prilocaine cream (EMLA) for topical anaesthesia before vascular access. Br J Anaesth 2009;102:210-5.

3. Sawyer J, Febbraro S, Masud S, Ashburn MA, Campbell JC. Heated lidocaine/tetracaine patch (Synera, Rapydan) compared with lidocaine/prilocaine cream (EMLA) for topical anaesthesia before vascular access. Br J Anaesth 2009;102:210-5.

4. Yamamoto LG, Boychuk RB. A blinded, randomized, paired, placebo-controlled trial of 20-minute EMLA cream to reduce the pain of peripheral i.v. cannulation in the ED. Am J Emerg Med 1998;16:634-6.

5. Newbury C, Herd DW. Amethocaine versus EMLA for successful intravenous cannulation in a children's emergency department: a randomised controlled study. Emerg Med J 2009;26:487-91.

6. Predel HG, Koll R, Pabst H, Dieter R, Gallacchi G, Giannetti B, et al. Diclofenac patch for topical treatment of acute impact injuries: a randomised, double blind, placebo controlled, multicentre study. Br J Sports Med 2004;38:318-23.

7. Dutta A, Puri GD, Wig J. Piroxicam gel, compared to EMLA cream is associated with less pain after venous cannulation in volunteers. Can J Anaesth 2003;50:775-8.

8. Agarwal A, Yadav G, Gupta D, Tandon M, Dhiraaj S, Singh PK. Et al. Comparative evaluation of myolaxin and EMLA cream for attenuation of venous cannulation pain: a prospective, randomised, double blind study. Anaesth Intensive Care 2007;35:726-9.

9. Richman PB, Singer AJ, Flanagan M, Thode HC Jr. The effectiveness of ice as a topical anesthetic for the insertion of intravenous catheters. Am J Emerg Med 1999;17:255-7.

10. Hijazi R, Taylor D, Richardson J. Effect of topical alkane vapocoolant spray on pain with intravenous cannulation in patients in emergency departments: randomised double blind placebo controlled trial. BMJ 2009;338:b215.

11. Hartstein $\mathrm{BH}$, Barry JD. Mitigation of pain during intravenous catheter placement using a topical skin coolant in the emergency department. Emerg Med J 2008;25:257-61.

12. Gerhardt RT, King KM, Wiegert RS. Inhaled nitrous oxide versus placebo as an analgesic and anxiolytic adjunct to peripheral intravenous cannulation. Am J Emerg Med 2001;19:492-4.

13. Robinson PA, Carr S, Pearson S, Frampton C. Lignocaine is a better analgesic than either ethyl chloride or nitrous oxide for peripheral intravenous cannulation. Emerg Med Australas 2007; 19:427-32.

14. Peter DJ, Scott JP, Watkins HC, Frasure HE. Subcutaneous lidocaine delivered by jet-injector for pain control before IV catheterization in the ED: the patients' perception and preference. Am J Emerg Med 2002;20:562-6.

15. Auerbach M, Tunik M, Mojica M. A randomized, double-blind controlled study of jet lidocaine compared to jet placebo for pain relief in children undergoing needle insertion in the emergency department. Acad Emerg Med 2009;16:388-93.
16. Singer AJ, Regev R, Weeks R, Tlockowski DS. Laser-assisted anesthesia prior to intravenous cannulation in volunteers: a randomized, controlled trial. Acad Emerg Med 2005;12:8047.

17. Singer AJ, Weeks R, Regev R. Laser-assisted anesthesia reduces the pain of venous cannulation in children and adults: a randomized controlled trial. Acad Emerg Med 2006;13:6238.

18. Becker BM, Helfrich S, Baker E, Lovgren K, Minugh PA, Machan JT. Ultrasound with topical anesthetic rapidly decreases pain of intravenous cannulation. Acad Emerg Med 2005; 12:289-95.

19. Agarwal A, Sinha PK, Tandon M, Dhiraaj S, Singh U. Evaluating the efficacy of the valsalva maneuver on venous cannulation pain: a prospective, randomized study. Anesth Analg 2005;101:1230-2.

20. Usichenko TI, Pavlovic D, Foellner S, Wendt M. Reducing venipuncture pain by a cough trick: a randomized crossover volunteer study. Anesth Analg 2004;98:343-5.

21. Maki DG, Ringer M. Risk factors for infusion-related phlebitis with small peripheral venous catheters. A randomized controlled trial. Ann Intern Med 1991;114:845-54.

22. Bijur PE, Silver W, Gallagher EJ. Reliability of the visual analog scale for measurement of acute pain. Acad Emerg Med 2001;8:1153-7.

23. Bhargava R, Young KD. Procedural pain management patterns in academic pediatric emergency departments. Acad Emerg Med 2007;14:479-82.

24. Sado DM, Deakin CD. Local anaesthesia for venous cannulation and arterial blood gas sampling: are doctors using it? J $R$ Soc Med 2005;98:158-60.

25. Walco GA, Cassidy RC, Schechter NL. Pain, hurt, and harm. The ethics of pain control in infants and children. $\mathrm{N}$ Engl J Med 1994;331:541-4.

26. Zempsky WT. Pharmacologic approaches for reducing venous access pain in children. Pediatrics 2008;122:140-53.

27. Oakbrook Terrace. Joint Commission on Accreditation of Healthcare Organizations. Improving the quality of pain management through measurement and action. Mar 2003.

28. Gold MS, Gebhart GF. Nociceptor sensitization in pain pathogenesis. Nat Med 2010;16:1248-57.

29. Fatovich DM, Jacobs IG. A randomized controlled trial of buffered lidocaine for local anesthetic infiltration in children and adults with simple lacerations. J Emerg Med 1999;17:2238.

30. Serinken M, Karcioglu O, Kutlu SS, Sener S, Keysan MK. A survey of needlesticks and sharp instrument injuries in emergency health care in Turkey. J Emerg Nurs 2009;35:205-10.

31. Liu SW, Zane R. Peripheral intravenous access. In: Roberts $J R$, Hedges JR, editors. Roberts clinical procedures in emergency medicine. 5th ed., Philadelphia, PA: Saunders; 2009. p. 402-12. 